\title{
8 "How to Turn Accumulated Knowledge into Action": Uptake, Public Petitions, and the Climate Change Debate
}

\begin{abstract}
This chapter focuses on how the impasse between climate change evidence and the public's acceptance of and action on climate change might be explained by an exploration of the concept of uptake in Rhetorical Genre Studies and by an exploration of the public genres that participate in climate change activism. Attention to genre uptakes - to the interconnections, interplays, and transactions between genres - can enrich an understanding of genres as social actions by focusing attention on the factors (material, social, affective, embodied, and technological) that influence the mobilization of knowledge and action between and across genres. Focusing on the uptake of a particular public genre, the petition, and on the actions/interactions that take place between and around the act of petitioning, the chapter provides further insight into the forces that shape uptakes of petitions, particularly climate change petitions, and that limit and enable social action on climate change. An examination of petitions (and their uptakes) as complex sites of transaction can also draw attention to mobilizations and actions that may happen along the pathway to uptake and social action - mobilizations in process that can lead to interventions in the climate change debate.
\end{abstract}

\subsection{Introduction}

Uptake is first the taking of an object; it is not the causation of a response by an intention. (Freadman, 2002, 48)

In November 2017, at the end of what was widely regarded as a year of setbacks in US efforts and leadership to address climate change, and twenty-five years after the Union of Concerned Scientists issued the "World Scientists' Warning to Humanity," scientists from around the world published "World Scientists' Warning to Humanity: A Second Notice" (Ripple et al). Appearing in the Viewpoints section of the December 2017 issue of the journal BioScience and including 15,364 scientist signatories from 184 countries, the article has since been endorsed by an additional 4,404 scientists on the Alliance of World Scientists' website. The Alliance of World Scientists describes itself as

a new international assembly of scientists, which is independent of both governmental and non-governmental organizations and corporations. We submit, that in order to prevent wides- 
pread misery caused by catastrophic damage to the biosphere, humanity must practice more environmentally sustainable alternatives to business-as-usual. Our vital importance and role comes from scientists' unique responsibility as stewards of human knowledge and champions of evidence-based decision-making. The main goal of the AWS is to be a collective international voice of many scientists regarding global climate and environmental trends and how to turn accumulated knowledge into action. (Alliance of World Scientists, 2017)

Scientists' near unanimous agreement about the fundamentals of climate change and steps needed to address it have been well-documented, but "how to turn accumulated knowledge into action" has been a source of frustration, enough so that world scientists felt the urgent need to issue the "second notice" warning to humanity.

Recalling the 1992 world scientists' warning that we cut greenhouse gas (GHG) emissions and phase out fossil fuels, reduce deforestation, and reverse the trend of collapsing biodiversity or face "substantial and irreversible harm" to our biosphere, the authors and signatories of the Second Notice warn that since 1992,

with the exception of stabilizing the stratospheric ozone layer, humanity has failed to make sufficient progress in generally solving these foreseen environmental challenges, and alarmingly, most of them are getting far worse (...) Especially troubling is the current trajectory of potentially catastrophic climate change due to rising GHGs from burning fossil fuels (Hansen et al. 2013), deforestation (Keenan et al. 2015), and agricultural production - particularly from farming ruminants for meat consumption (Ripple et al. 2014). Moreover, we have unleashed a mass extinction event, the sixth in roughly 540 million years, wherein many current life forms could be annihilated or at least committed to extinction by the end of this century. (Ripple et al., 2017, 1026)

The authors and signatories conclude that, twenty-five years later, we have not heeded the first world scientists' warning. "Soon," they write, "it will be too late to shift course away from our failing trajectory, and time is running out. We must recognize, in our day-to-day lives and in our governing institutions, that Earth with all its life is our only home” (Ripple et al., 2017, 1028).

With so much at stake and what the editors of this volume describe as "the gap between the near-unanimous agreement in science about the basics of human made, or anthropogenic, climate change (ACC), and the widespread lack of acceptance of this agreement in the public sphere". The Alliance of World Scientists' question of "how to turn accumulated [scientific] knowledge into action" is more urgent than ever. To better understand the impasse between overwhelming scientific evidence of climate change and urgency/action on the part of citizens and political leaders, we will turn to genre and uptake and the role they play in the mobilization of knowledge, for as Amy Devitt argues in her contribution to this volume, genres matter for social action: "their conventions, norms, actions, systems, and potential invisibility direct the debate in sometimes unnoticed and sometimes unintentional ways" (add page \#). In order to explore the ways genres direct the debate around climate change, we will begin by focusing on how the impasse between climate change evidence and the public's acceptance of and action on climate change might be explained by an understanding of genre uptakes as complex sites of selection and genre performance 
and by an exploration of the affective, social, and material factors that shape uptake. Understanding how genres and their uptakes direct rhetorical and social actions also reveals possibilities for intervening in and redirecting these actions. As a case study, we will examine the uptake of a particular public genre, the petition, with a focus on the affordances and constraints of petitioning and the relationship between what Dylan Dryer (2016) calls the "uptake affordances" of petitions (the opportunities or constraints that shape encounters with and uptakes of petitions) and the "uptake enactments" (the act of producing a response). As we examine this complicated relationship between rhetorical action and social change, we will draw on illustrations/ examples of climate change petitions, showing how a number of prior uptake strategies historically connected to petitioning seem to resurface, reemerge, or recur in a contemporary context and remain integral to carrying out a petition's actions. As we hope to show, attention to uptake's complex relationship to genre can help explain how other forces intervene in and redirect rhetorical and social action at the same time as it draws attention to mobilizations and actions that may not be as apparent. Paying attention to the forces that shape genre uptakes can help us examine where breakdowns in the climate debate happen and how to intervene.

In what follows, we begin by defining genre's relationship to uptake and how attention to genre uptake can reveal the often invisble forces directing social action. From there, we will demonstrate uptake at work in the genre of the petition, with specific reference to climate change. As we hope to show, recognizing the complex uptakes surrounding petitioning reveals how genres can be used to intervene in and redirect climate change action.

\subsection{Genre and Uptake}

Since its beginnings, scholarship in Rhetorical Genre Studies (RGS) ${ }^{1}$ has been interested in the inter- and intra-generic relations that shape individuals' genre performances - what Anne Freadman (1994, 2002), extending J.L. Austin's concept of uptake in speech act theory, has called genre uptakes. Attention to genre uptakes to the interconnections, translations, and pathways between genres - enriches an understanding of genres as social actions at the core of RGS' definition of genre. While genres orient us in relation to recurring situations and provide strategies for responding to and acting in situations, and while genres, as Dylan Dryer explains, "persist because they frame what they permit as that which is possible" $(2008,506)$, it is only in the uptakes they routinize (but never completely determine) that genres are performed - are taken up - as social actions.

1 See the groundbreaking work of Carolyn Miller, Charles Bazerman, Aviva Freedman and Peter Medway (1994), Amy Devitt, Catherine Schryer, David Russell, and Carol Berkenkotter. 
In How to Do Things with Words (1962), J.L. Austin briefly mentions the idea of uptake as a way to explain how illocutionary force becomes a perlocutionary effect - how, that is, an intentional utterance helps to produce an effect under certain conditions. Within Austin's theory of speech acts, uptake is offered as a fairly straightforward process, secured by the apprehension (and then translation) of an intended illocutionary act. Freadman expanded and complicated Austin's causal theory of uptake in order to account for the interplays and trans-actions between genres, and, in so doing, made uptake a core concept in genre research. As Freadman is careful to note, uptake does not depend on causation (as in a job advertisement causes a job application) but rather on selection. Uptake, she explains, "selects, defines, or represents its object ... This is the hidden dimension of the long, ramified, intertextual memory of uptake: the object is taken from a set of possibilities" $(2002,48)$. By shifting our attention from causation to selection, Freadman offers uptake as a complex site of transaction, one informed by historical, material, political, affective, socio-economic, and ideological forces.

In Freadman's formulation of the relationship between genre and uptake - a relationship that Freadman understands as fundamental to how we use genres and how genres operate - genres condition and secure uptakes (Freadman, 2002, 42). One of the ways that genres help us perform social actions is by directing rhetorical force, moving it in typified directions, at times formalized in what John Swales has called "genre chains" (2004), to secure certain uptakes. Sune Auken has described this relational interchange, in which the use of one genre in turn acts as an invitation or request for another genre, as "in effect taking part in a social perpetuum mobile" $(2018,19)$. In exploring the relationship between Swales' concept of genre chains and Freadman's concept of uptake, Auken notes how genre chains mobilize uptakes in fairly regularized, sequential ways in which each genre is an uptake of the former: "a genre chain is a formalized series of uptakes. Genre chains are bound; they move in a particular order, and relate to one another in a particular hierarchy” (20). However, outside of formalized genre chains (and even in some cases within them), uptakes are more dynamic and unpredictable. As Auken observes, "an uptake can easily follow a chain, but it can also deviate from, turn, or twist the purpose of the chain. Also, one may insert one or more new genres into the process in an attempt to achieve a desired purpose" (20). ${ }^{2}$

This is why, as Freadman demonstrates, uptakes are not simply the consequences of genres - the meeting of a genre expectation. Uptakes also depend on dynamic relations between genres that enable the movement of knowledge and actions across

2 For more on the stability and variation inherent in the relationship between an utterance and its genre, and the role that generic structures play in the interpretation of works of literature, which has implications for understanding uptake, see Auken's “Genre and Interpretation” (2015a) and "Utterance and Function in Genre Studies: A Literary Perspective” (2015b). 
them. In the Prison Notebooks, Antonio Gramsci (1971) writes, "The starting-point of critical elaboration is the consciousness of what one really is, and is 'knowing thyself' as a product of the historical processes to date, which has deposited in you an infinity of traces, without leaving an inventory" (323). As it pertains to genre research and teaching, Gramsci's critical elaboration points to the hidden dimension of uptake, which refers to the historical processes that stabilize relations and pathways between genres in ways that condition and secure, but never guarantee, certain effects. For example, as noted earlier, within speech act theory uptake refers to how an illocutionary act produces a perlocutionary effect - how, for instance, someone saying "it is hot in here" results in someone else, under certain conditions, opening a window. A set of relations has to exist in order for this uptake (this selection from a set of possibilities) to happen: the speaker's relation to others in the room; an interpretation of the utterance as referring to temperature and not, say, mood; a relationship between the location of a window and a person's ability/authority to open it; etc. Uptake, as such, refers both to the effect and the set of relations that produce that effect. As Gramsci's observation makes clear, though, the relations that inform our selection processes are often hidden. How to account for these relations when an inventory is not easily available is a major challenge uptake poses to the study of genre and its relationship to social action. And yet, we contend, critical attention to uptake relations provides valuable insight into how genres like the petition can be used to redirect public discourse around climate change.

Since first introducing the concept of uptake to genre research, Freadman's work has consistently alerted us to the ways that genre uptakes are complex sites of transaction that challenge a view of genre mobilization as located in genre knowledge and as being synonymous with human agency and intentionality. ${ }^{3}$ For instance, in Freadman's early definition of uptake as "the bidirectional relation that holds between" genres (Freadman, 2002, 40; emphasis added), the pivotal term holds suggests a relational force or interplay that operates between genres. Uptakes, Freadman's definition suggests, are the result not of causation but of relation and selection - a set of relations that are held together in ways that make certain selections (and not others) possible and that as a result condition and secure certain outcomes (and not others). When studying uptake, then, we need to pay attention to the relations drawn, managed, and sponsored that enable the selection and taking up of knowledge and actions across genres, which enable and limit rhetorical and social movement. When Freadman writes that "uptake is first the taking of an object; it is not the causation of a response by an intention" (48), then, she refers to the relations between genres that uptakes hold and that make possible certain takings. These takings are not caused by genre but by the set of relations that hold between them. The seams between genres

3 See "Uptake” (2002), The Machinery of Talk (2004), “The Trap and Trappings of Genre Theory” (2012), and "Where is the subject?" (2014). 
that uptakes weave and "hold," in other words, make movements and translations between and across genres possible. Uptake, then, is a vital part of genre knowledge, but because it takes place within a complex site of transaction, it also exceeds genre knowledge.

As "the local event of crossing a boundary" (43), uptake draws our attention not only to the relations between genres but also to how individuals move and translate across genres. It is especially when they occur across intergeneric boundaries, Freadman notes, that uptake translations are "least automatic and most open to mistake or even to abuse" (44) since they are most subject to relations of power and other extra-textual forces, as in the case of translating scientific knowledge about climate change into public action. Certain routinized uptakes, especially within bounded and regulated institutional contexts, follow well-worn, expected directions and are thus habitually and predictably enacted. But when moving across generic fields, as is required when scientific knowledge gets translated to public actions, other uptake relations come into play and exert force on the relations between scientific knowledge and its public uptake, in ways that affect how science is taken up - that is, how scientific knowledge is selected from a set of possibilities. What makes uptakes in this case especially interesting is that they compel us to pay attention to the extra-textual factors that inform genre performances, including the historical-material conditions and dynamics of agency and power that function between, hold together, and shape genre performances. As Freadman more recently put it:

\footnotetext{
No genre can do more than predict the kind of uptake that would make it happy, and no speaker or writer can completely secure an uptake. This is partly because no discursive event is a pure example of any genre, and partly because of the unpredictable historical complexity of its moment and its ongoing action. We cannot [...] reflect productively on uptake outside of discussions of genre, nor is it productive to theorize the action of genres without uptake. Genre is destabilized by uptake even as it asserts its power. $(2012,560)$
}

In short, uptake helps us understand how systemic, normalized relations between genres coordinate complex forms of social actions - how and why genres get taken up in certain ways and not others and what gets done and not done as a result. To study uptake, we need to pay attention to the spaces in between genres - the meso practices, interplays, transactions, and translations as well as the meta-genres (Giltrow, 2002) and intermediary genres (Tachino, 2012; 2016) that mobilize knowledge and action between and across genres. Focusing on these trans spaces, genres, and actions draws our attention to the seam-work that holds genres together in order for knowledge to move across them: who and what sponsors, sanctions, and manages our ability and willingness to engage in genre transaction work, and to the forces that make movement across genres possible, including the affordances, systems of valuation, materialities, embodiments, tools, media, technologies, and affective factors that authorize, manage, and sponsor the movement of knowledge across contexts and domains. Such a view of uptake can help explain why it can be so hard to turn 
accumulated scientific knowledge into action, despite the mobilization of that knowledge in various professional, public, and popular media genres. Trying to understand how and why accumulated scientific knowledge has not turned into action with the urgency it needs to requires us to understand the phenomenon of movement itself, especially the entangled relationship between the mobilization of scientific knowledge and the material conditions, affective factors, and socioeconomic values that mediate it. Becoming mindful of this movement and its guiding forces, as Devitt, in this volume, argues, takes us a step closer towards making genres work for social action rather than only as social actions - in particular, making genres of the climate change debate work for transformative social action on climate change.

\subsection{Dimensions of Uptake in the Mobilization of Knowledge and Action}

In the previous section, we described how uptakes result from/are made possible through configured, normalized, and activated relations between genres - relations that shape what comes to matter and how it gets taken up as such. Karen Barad (2007) has explored the dynamic relationship between matter and meaning, arguing that "mattering is simultaneously a matter of substance and significance" (3). According to Barad, how something comes to matter (have substance) is entangled with how it is made significant. How an utterance such as "it is hot in here" comes to matter (have substance in the form of someone opening a window) depends on the significance accorded to it. Uptakes are, in part, how we recognize significance in one genre and take it up as substance. In this way, uptakes make genres matter. But this process of mattering, as we have described, is subject to forces greater than genre alone, no matter if genres seek to secure and condition certain uptakes. For example, in the case of the Alliance of World Scientists' warning to humanity, what would make their Second Notice matter is if governmental agencies and the public take up their recommendations. But for these recommendations to become substance, they first need to be made significant alongside or in relation to other kinds of significations, which exert their gravitational push and pull on how the Second Notice gets taken up.

Scholarly analyses of climate change skepticism have examined the economic, cultural, political, cognitive, sociological, and ideological influences on why individuals remain skeptical of climate change (see Dunlap, 2013; Hamilton, 2010; Jacques, 2006; Thompson, 2003; Whitmarsh, 2011). In their review of literature, Van Rensburg and Head (2017) note a prevailing research strand that identifies how "worldviews are acting indirectly, as background dispositions that are reinforced by various cognitive and psycho-sociological mechanisms" (3) to shape climate change denial. Van Rensburg and Head's textual analysis of a well-known Australian climate change skeptic's opinion pieces reveals, in addition, the discursive patterns and specific terms through which climate change skepticism circulates and is perpetuated. "We argue," 
they conclude, "that examining the specific objections of sceptics is important for devising more effective responses. We argue that climate communicators and practitioners should constructively, patiently, and persistently respond to sceptical criticisms, instead of trying to starve sceptics of public exposure by refusing to engage them" (8). Such research provides insights into the competing forces that shape and limit the uptake of scientific knowledge about climate change, especially in regions where individuals perceive environmental regulations as a threat to their livelihoods, culture, and economy. ${ }^{4}$

The entangled and at times competing forces that shape what comes to matter (to be made significant and come to have substance) in the taking up of genres requires closer scrutiny if we are to more fully understand how to turn accumulated scientific knowledge into action. In his recent chapter "Disambiguating Uptake: Toward a Tactical Research Agenda on Citizens' Writing,” Dylan Dryer (2016) begins the process of identifying different elements involved in uptake as a phenomenon. Dryer identifies five elements in particular: uptake affordances, uptake artifacts, uptake enactments, uptake capture, and uptake residue. Uptake affordances refer to the conditions and invitations that facilitate an uptake - something that is offered to be taken up (65-68, 70-71). By paying attention to uptake affordances, researchers are able to focus on "the opportunities and constraints in the conventions that precede and shape the uptake encounter" (70). Uptake artifacts refer to the texts or objects produced in response to other texts, the artifacts that result from an uptake $(65,71)$. Uptake enactments refer to the act of producing an utterance or text in response to uptake affordances - the performance or undertaking of an uptake $(65,70,72,74)$. Uptake capture refers to the cognitive or affective consequences of uptake, the way "repeated encounters with genres have lingering effects on what writers see - or indeed are able to see - as the realm of the possible..." (65). Researchers focused on uptake captures examine what successive uptakes do to readers and writers, how they become sedimented as dispositions. Uptake residue, which for Dryer is closely related to uptake capture, refers

4 A recent story in ScienceDaily (2017), "Understanding Alternative Reasons for Denying Climate Change Could Help Bridge Divide,” profiled sociologist Jacob Lipsman's research on climate change denial which challenges mainstream criticism that climate skeptics are out of touch, ignorant, or unwilling to accept scientific facts about climate change. In particular, Lipsman examined "the links between attitudes about climate change and local discursive and political processes surrounding coastal restoration issues" in two Louisiana parishes adjacent to the mouth of the Mississippi River, a region that has lost over 1,800 square miles of land to coastal erosion (ScienceDaily, 2017). As Lipsman concludes, "If an individual or a community is resistant to the idea of climate change for economic or social reasons, climate advocates will not be able to effectively communicate with these individuals about climate change simply by presenting more data [...]. By better understanding the processes of climate change denial, climate advocates will be better equipped to have an effective dialogue with individuals and communities that are skeptical of these ideas" (ScienceDaily, 2017). 
to the accumulation and sedimentation of relations/configurations that accrue over time as a result of repeated uptakes and become part of shared, cultural memory (66). These dimensions of uptake clearly interact: "the more normalized the uptake affordance, the more instantaneous and "natural" the moment of uptake capture; the more powerful the uptake artifact, the more habitual the uptake enactment, and the more deeply sedimented the uptake residues" (66). This interaction is particularly acute within genre chains, as we discussed earlier. Dryer concludes that "we must attend to the multifaceted ways uptake unfolds so we can investigate each dimension empirically and study public participation in ways that do justice to its complexity" (66). As we will show in the following case study of petitioning, examining these dimensions of genre uptake can help provide insight into the complex relations and processes involved in how accumulated scientific knowledge about climate change can be turned into public action.

\subsection{Taking up a Public Genre: Petitioning for Climate Change}

Following our previous examination of the complex uptake performances that take place in-between and around genres, in this section we will focus on the uptake of a particular public genre, the petition, and the performances that take place inbetween and around the act of petitioning. Drawing on Dryer's multiple concepts of uptake, this section will examine the various relational forces that shape uptakes of petitions, specifically climate change petitions. Dryer notes the significance of studying genre uptake in the public sphere and the role of Rhetorical Genre Studies (RGS) in enacting social change:

These studies are of more than theoretical interest: an enormous amount of public and publicsector writing on these topics will take place in the next decades as sea-level rise forces us to triage our coastal cities' built resources. RGS must help shape the texts that invite citizens to contribute meaningful writing and ensure that citizens' writing is taken up in the most productive ways. $(2016,64)$

By looking outside the academy and beyond traditional academic genres, particularly at public genres that work to mobilize diverse publics and to motivate and bring about change, we can learn much about the relationship between rhetorical action and social change. The public petition, in particular, is a genre whose exigency is social change. It functions rhetorically to respond and to motivate response - in the US context, "to petition the government for a redress of grievances" (constitutionus.com). Petitions, by mediating between citizens and authorities, operate in the middle spaces, and as an intermediary genres of sorts, can help (re)direct, manage, and intervene in available uptakes. We noted previously the competing forces at play in uptakes, and petitions function as an in-between space where uptakes might be brokered and redirected. If uptake offers a vision of genre as relational - a vision of genre in inter- 
play with other genres or a vision of genre as movement - then the genre of the petition, as a tool of mobilization, can provide insight into the material, social, affective, and agentive factors that shape uptakes of petitions and that limit and enable social action. Importantly, petitions can also draw attention to mobilizations and actions that may not yet appear as such - mobilizations in process. By revealing such mobilizations in process, uptake can help climate change activists use petitions more effectively to lay groundwork for social action.

The following case study, then, will examine the "uptake profiles" of petitions or "the social motives, relations, values, and assumptions embodied within a genre that frame how, why and when to act” (Bawarshi \& Reiff, 2010, 77), with the goal of continuing to take up the central theme of this edited volume - the "activistic" focus on how genres can influence social change. We will begin with a brief description of the genre of the petition and its historical evolution before moving on to examine more contemporary petitions, including climate change petitions. In addition, we will explore the relationship between "uptake affordances" of petitions - or the "opportunities or constraints...that precede and shape" encounters with and uptakes of petitions (Dryer, 2016, 65) - and "uptake capture" or the affective, cognitive and embodied factors that shape the uptake of petitions (65), specifically petitions related to environmental activism and climate change. Finally, we will examine how participating in climate change petitions might both limit and enable "uptake enactments" or the act of producing a response to climate change.

\subsection{Petitions, Uptake Affordances, and Uptake Captures}

Historically, petitions have afforded opportunities for citizens to appeal to established authorities and to have a voice in civic matters. Public petitions, since long before the Enlightenment, have been rhetorical sites of political participation, playing a significant role in revolutionary rebellions against taxes and the Whiskey Rebellion (both of which came about due to a lack of response to the glut of petitions) and in reforms due to temperance petitioning, antislavery and antiremoval campaigns, or the suffrage movement. Historical studies of the petition have examined the impact of petitioning on the maintenance of social order in Roman Egypt (Kelly, 2011), on origins of democratic culture in early-modern England (Zaret, 2000), and on political participation in early colonial America (Bailey, 1979; Maier, 1991). Other studies have focused specifically on women's activism and the role of petitioning in $19^{\text {th }}$-century Native American anti-removal and antislavery movements (Portnoy, 2005; Zaeske, 2003); on transnational activism and the role of citizen-petitions in the North American Free Trade Agreement (Graubart, 2008); or on the role of petitions in the decentralization of Chinese authoritarianism (Chen, 2016). Lex Heerma van Voss (2001) has argued that "petitions are social history...showing the evolving ways in which individuals 
and social movements used petitions" (3), and he further reflects on the "global phenomenon" of those in the past who used their right to petition,

[...] from Egyptian building workers in pharaonic times to illiterate Ecuador Indians in 1899; from anti-Catholic English women in 1642 to French workers asking for the repeal of the livret ouvrier in 1847; from Italian peasants complaining about noble banditry in 1605, to Brazilian slaves vindicating their rights against their owner in 1823; from western European early modern guild members to German Democratic Republic workers demanding improvement of economic efficiency, or voicing consumer demands. (1-2)

The studies featured in van Voss' edited collection further demonstrate this global phenomenon of petitioning, with studies of petition movements in early modern central Europe, early modern Italy, $18^{\text {th }}$-century France, colonial Andhra, and early $20^{\text {th }}$-century Republic of Byelorussia and nationalist China, among others.

Despite a number of wide-ranging historical and sociological studies of petitions as a force for social action, there have been relatively few studies of the petition from a rhetorical or RGS perspective, with the exception of Zaeske's analysis of how the language of women's antislavery petitions reflects their shifting political identities; Thieme's related study (2006) of uptake and genre in the Canadian suffrage debate (which focuses on a number of other social movement genres that move beyond petitions); and Reiff's study (2016) of the material factors (cultural, economic, geographic, technological) affecting the rhetorical action of the petition. Nonetheless, the genre of the petition fits squarely into what Devitt, in this volume, describes as a genre that "operate[s] not just as social action but also for social action" (add page \#), which makes it a meaningful genre for exploring the interaction of rhetorical and social action. Through its conventions, the petition affords citizens a pathway to intervening in public matters and functions as a tool for coordinating civic actions. While the petition's textual features have shifted and changed across time, the genre's conventions include the following salient features or sequence of rhetorical "moves"5:

1) an opening address to an authority;

2) an expression of the grievance;

3) a recommendation for action;

4) a list of signatories.

The list of signatories, in particular, is an affordance that precedes and shapes the uptake and "fosters new networks by virtue of the process of gathering signatures" (Carpenter, 2003, 1). These conventions, then, work to facilitate uptake as petitions make possible opportunities for the disempowered to mobilize support, make their

5 John Swales (1990) modeled an approach to genre analysis that begins with identifying a genre's typical moves. Our identification of the petition's typical moves lends itself to a Swalesian move analysis. 
opinions known to those in power, and mediate between critique - bringing forward a grievance - and change, or the redress of the injustice.

Uptake affordances of petitions, historically, have been shaped by what Dryer (2016) calls "uptake capture" - the dispositional, affective, and embodied influences on uptake - or what he describes as the "cognitive or affective consequences of uptakes" (65). The embodied experiences of petitioners and their affective consequences can be seen most readily in early petitions, where petitioning bodies engaged (rather strategically) in rhetorical action under specific physical and spatial conditions. For example, in pre-revolutionary England, in order for citizens to have their petitions taken up and acted upon by authorities, they were physically presented to rulers, often thrust into their hands. This physical presentation of petitions, chronicled by David Zaret (2000), began as early as the reign of Edward III (1312-1377) when "petitioners sought him out when he was hunting in the royal forests or fighting on the border" (85). With the popularization of petitioning and "incessant demands from rich and poor petitioners," this trend continued, extending from James I (1556-1625), who was stalked in the back stairways of the palace or while on hunts in the royal forest by those presenting petitions, to his successor Charles I (1600-1649), who often sent two ushers ahead of the king to prevent petitioners from thrusting petitions into the king's hands (85). Later, petitioners in the $17^{\text {th }}$ and $18^{\text {th }}$ century would march their petitions to Parliament or walk their petitions to the county court for collection, and $19^{\text {th }}$-century female anti-slavery petitioners canvassed, went door to door, gathered signatures, and talked to women face to face in sewing circles and literary societies - affective, interpersonal encounters that had "lingering effects" (Dryer, 2016, 65). An historical account of the circulation of local petitions in the antebellum public further demonstrates these embodied, dispositional and affective influences on and of uptake:

\footnotetext{
These were your neighbors who sought you out in your home or field or forest, behind your counter, at your desk, with your team - in a time more innocent than ours, before such canvassing was commonplace and at a time when a petition meant something....The woman who approached you with her petition in hand, at Wednesday night prayer meeting, or in your barbershop or at your door, would probably be somebody you knew, or somebody who knew somebody you knew. (Miller, 1995, 305)
}

Earlier we referred to Freadman's definition of uptake as "the bidirectional relation that holds between" genres, and the embodied interactions of petitioners, who knew and had relationships with petitioners, act as a kind of interpersonal capture - a building of and "holding" of relations that make certain uptake selections possible or that make genres, in this case the petition, matter. These uptake captures are, in an important way, preludes to actions, cultivating dispositions for later actions. For example, in $19^{\text {th }}$ century anti-slavery petition movements, signing a petition might encourage and coordinate further civic actions or "correspondence networks," such as women joining a female antislavery society, attending antislavery fairs or conven- 
tions, or making a donation to support the cause. Uptake capture, then, can create additional uptake affordances or conditions around petitions that invite additional uptakes. In the case of climate change, where public discourse (and skepticism) is powerfully shaped by economic, cultural, political, cognitive, sociological, and ideological influences, the uptake captures made possible through petitioning can become an important counterforce that lays the groundwork (affordances) for a different relation to and taking up of the climate change debate. At the same time, it is interesting to consider how these uptake affordances - the conditions and invitations that facilitate an uptake - and uptake captures, or interpersonal relationships that shape uptakes and consequences, can become constraints as we move to more contemporary petitions, such as climate change petitions. Mailed petitions or electronic petitions are more distanced by time and space and more "disembodied," with more of a reliance on discursive and rhetorical strategies to promote mutuality and connectedness to shape uptakes. The actions that were coordinated by, for example, correspondence networks of women in the $19^{\text {th }}$ century are later coordinated by a network of genres that operate as an integrated rhetorical and epistemic site, as seen by the following mailed petition to "Save our Environment" (See Figure 1). This petition from the Natural Resources Defense Council (NRDC) was sent during the George W. Bush presidency, and depicts the genre network of petitions containing 1) a letter from the president of the organization and a high-profile person (organizations, such as NRDC, often include "personal messages" from more high-profile figures like Robert F. Kennedy and Robert Redford); 2) a fact sheet or action plan; 3) a petition written on the reader's behalf and addressed to the reader's congressional representatives or to other appropriate audiences; and 4) perhaps most significantly, a contribution card, which is often attached to the petition. These intergeneric texts of the petition work together to try to "turn accumulated knowledge into action" (Alliance of World Scientists) as they assemble fact sheets on climate change addressed to citizens alongside petition cards addressed to political leaders.

The uptake affordances - or "opportunities and constraints in the conventions that precede and shape the encounter" (Dryer, 2016, 65) - can easily be detected in the NRDC petition. The letter from a high-profile figure, Robert Redford - what Bawarshi (2016) has labeled an "uptake sponsor" (56) - does the work of opinion formation previously developed through face-to-face discussion and canvassing. In place of the more personalized human interaction, more contemporary print petitions include written letters and fact sheets, like the ones depicted in Figure 1, or personal testimonials that make emotional appeals, such as the appeal from Robert Redford, who decries the gutting of the Clean Air Act, deregulations favoring polluting industries, and the opening of national forests to drilling, logging, and mining: “These blatant special interest handouts are a radical departure from the values of environmental protection that most Americans hold dear." Without the embodied or relational transactions of face to face canvassing, print petitions must strategically create their own uptake captures or "lingering effects" that motivate action and response 


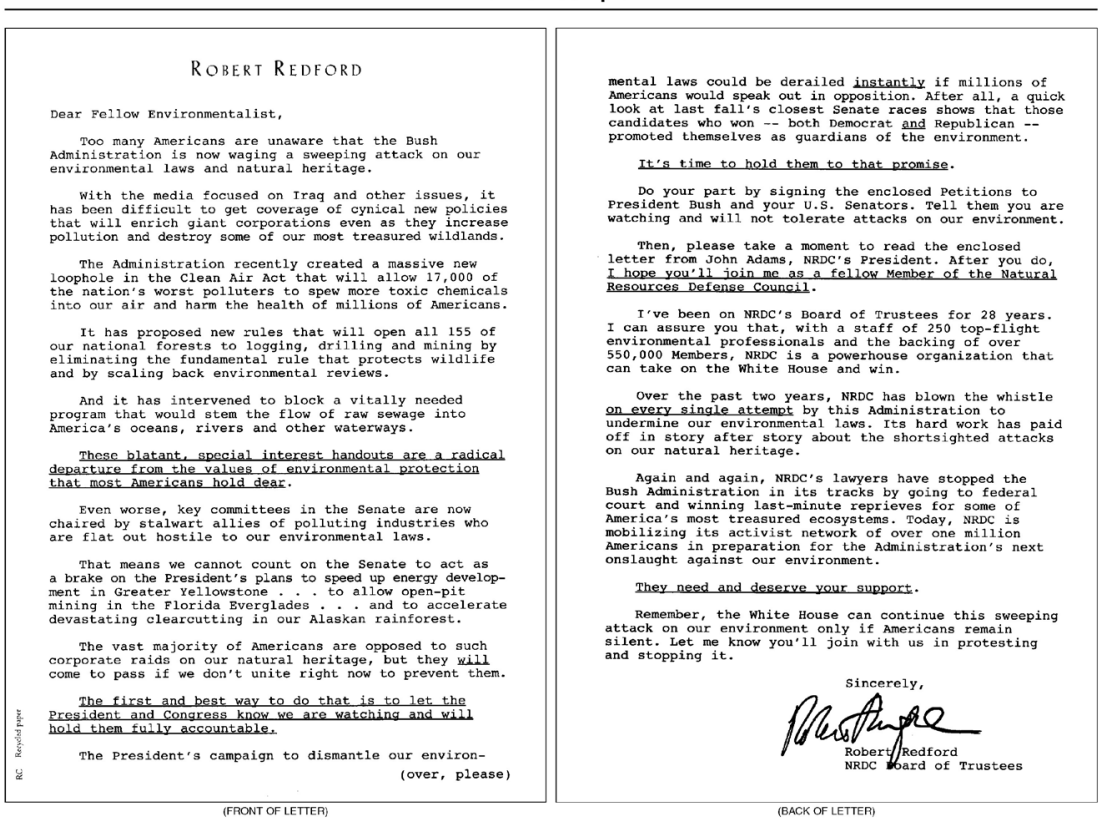

Petition Sample

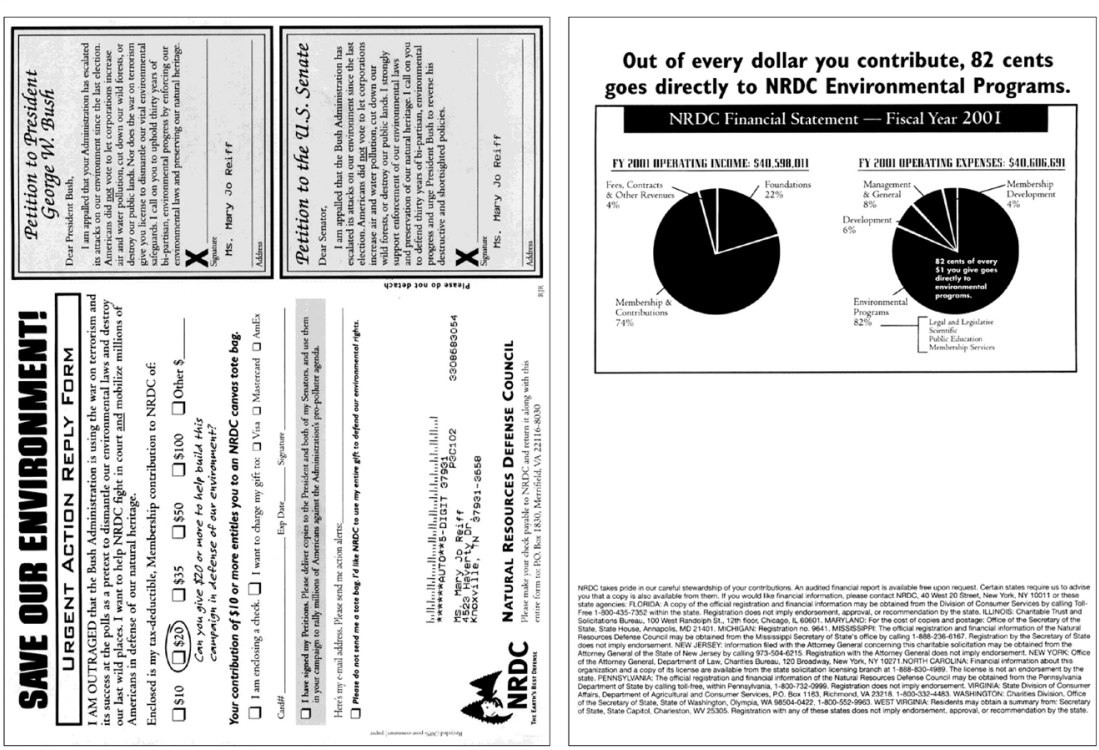




\section{Petition Sample}

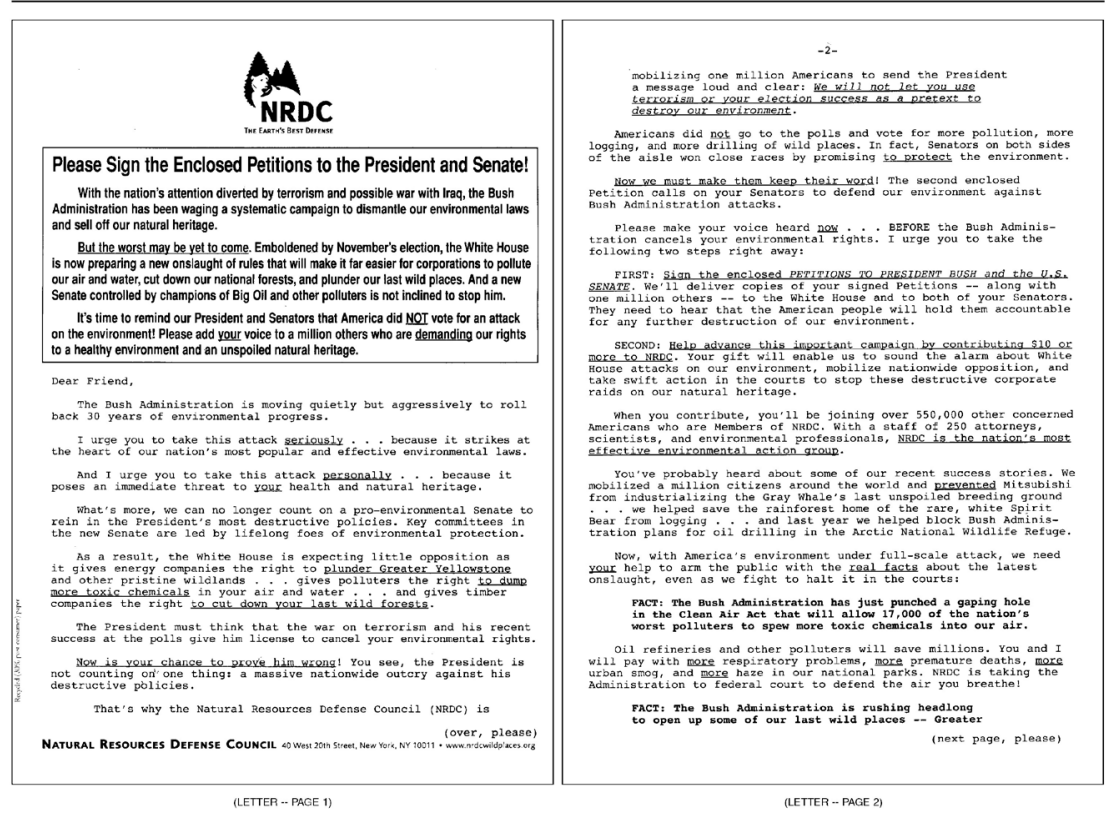

Petition Sample

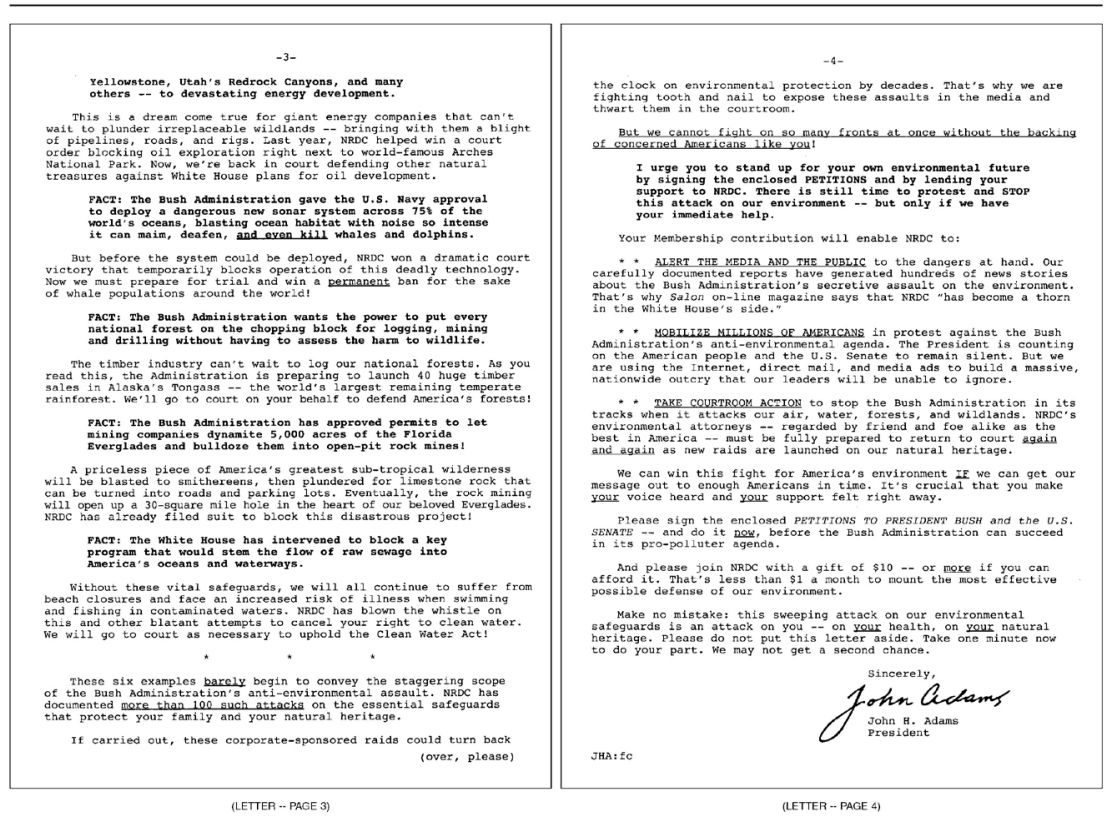

Fig. 1: National Resources Defense Council (NRDC) Petition. 
through the presentation of shocking facts (fact sheets describing the "dynamit[ing of] 5,000 acres of the Florida Everglades" or "the flow of raw sewage into America's oceans and waterways") and personal pleas by the president of the NRDC ("I urge you to stand up for your own environmental future by signing the enclosed petitions and by lending your support to NRDC”).

If uptake is the "contextualized, strategic performance of genres in moments of interaction" (Bawarshi, 2016, 45), then the shift from a small coalition of canvassers to large NPOs like the NRDC entails a shift in the tactical dimensions of the symbolic interchange as the sequence of uptakes becomes further removed. For example, the NRDC delivers this emotional plea to the President on behalf of citizens, with a space left for the petitioner to sign: "I am appalled that your administration has escalated its attacks on the environment.... I call on you to uphold 30 years of bi-partisan, environmental progress by enforcing our environmental laws and preserving our natural heritage" - a simulated uptake capture that can then become internalized as one's own position. The NRDC petition demands an active uptake in its action plan, and the role of agency here is interesting since citizens are asked to take action to "save our environment" by signing the petition and making a contribution so that the sponsoring organization can then take action by "alerting the media, mobilizing Americans, or taking courtroom action" (Fact Sheet). But what is the range of transformation permitted by this genre's "uptake profile" if the actions are taken on behalf of citizens by a mediating organization, thus delimiting the relationship between agency and action? Unlike early petitioners' presentation of their petitions, often in person, in contemporary petitions organizations express a grievance on the petitioner's behalf, while the petitioner's role consists of signing the petition and checking the contribution card that will enable the organization to coordinate social actions. While the petition might serve to inform recipients of anti-environmental policies and might mobilize support for the NRDC and for environmental causes in general, the direct interaction between citizens and authorities (particularly authorities with the power to affect climate change legislation) is mediated. This mediation reduces one of the rhetorical and social advantages petitions afford in redirecting climate change action. At the same time, as we see next, such mediation can make possible other uptake captures that can powerfully impact the climate change debate.

This mediation of uptakes - and mediation between citizens' petitions and authorities' responses - becomes even more pronounced as we consider how climate change petitions operate on a global scale. Hari M. Osofsky (2007) examines a petition filed in 2005 against the US government by US and Canadian Inuit citizens claiming that US climate change policy violates their rights as a culture that thrives on "land, ice, and snow" (697). The petition was filed with the Inter-American Commission on Human Rights and taken up by Sheila Watt-Cloutier, Chair of the Inuit Circumpolar Conference, in her statement before a UN conference on climate change. Osofsky notes what we would recognize as the unique "uptake affordances" of this "intersectional" petition: "It reframes a problem, typically treated as an environmental one 
through a human rights lens and moves beyond the confines of US law to a supranational forum" (676). In so doing, the petition works to shape "uptake capture" - to maximize the affective consequences of uptakes - by aligning global climate change with human rights and the rights of indigenous peoples. By bringing together climate change and human rights, the petition draws into play the various relational forces that shape uptakes. The petition also works to facilitate the conditions of uptake by mediating between the Inuit petitioners, the US government, and the Inter-American Commission on Human Rights.

The uptake affordances of "intersectional," global petitions and the relational forces that shape uptakes have also been affected by technology and digital media, as the next section will explore. The rise in online petitions has the potential to facilitate circulation of petitions across cultural and geographical boundaries. While such mediation reduces the possibility for direct interaction between citizens and authorities, it potentially increases the possibility for intervening in or brokering uptakes and intervening in the climate debate.

\subsection{The Uptake Affordances and Constraints of Online Petitions}

As we trace the historical evolution of the genre of the public petitions and the migration of petitions to online spaces, it is easy to see the potential affordances of online petitions, which have the ability to reach multiple, dispersed audiences and to mobilize broader networks of support across divides of institution, location and language. Media studies scholar danah boyd (2010) explains how the affordances of networked publics shape interactions and uptakes by making "one-to-many and many-to-many interactions far easier" (54) and by enabling people "to connect to one another across great distances" and "over extended periods" (53). The affordances of online petitions, then, are their ability to reach multiple, dispersed audiences and to mobilize broader networks of support across divides of institution, location and language.

At the time of this writing, there were multiple climate change petitions circulating online, with petitions sponsored by organizations ranging from the NRDC ("Demand the President Trump Restore America's Leadership on Climate Change”), to corporate entities, such as Ben and Jerry's ("If it’s melted, it's ruined!"). Multiple climate petitions were also created on various sites such as Care2Petitions or thepetitionsite.com ("Don’t Drill Off Our Coasts" and "Defend Starving Polar Bears"), Change.org ("Tell Trump to \#ActonClimate"), and MoveOn.org ("We the People of the US sign on to the Paris Agreement"), some of which are sponsored by high-profile individuals, such as Bianca Jagger and Human Rights Foundation's sponsorship of "An Urgent Call to World Leaders to Prevent Catastrophic Climate Change" (Moveon.org). Stephen Hale (2010) also points to global organizations like Avaaz - meaning "voice" in several European, Middle Eastern, and Asian languages - noting that this online international campaign "has grown at incredible speed" and demonstrates promise as a 
global movement seeking to break "the impasse between government, business, and individuals" (263).

To illustrate the affordances of online petitions - such as scalability - as noted by boyd above, the Avaaz petition ("Mega Climate Petition for 100\% Clean World") includes links to email, Facebook, and Twitter and boasts over 3.5 million signatures worldwide. Moveon.org's "We the People of the US sign on to the Paris Agreement" to be delivered to the US House and Senate and President Donald Trump - currently has 557,064 signatures. But while networked publics enable a greater scalability, this greater scalability can also be a constraint as questions of authenticity and credibility are raised. An article on “Authenticating Electronic Petitions” in Canada's online legal magazine, Slaw, further defines these constraints by posing the following questions: "But are the online petitions too easy because people can sign without much challenge, or because one can automate the signing and eliminate the people altogether? In other words, are they more likely to contain fraudulent signatures, phony names?" (Gregory, 2015, para. 6). A new system of e-petitioning used by the city government of Wellington, Australia, raises additional issues of the affordances and constraints of online petitions. While affording greater citizen engagement (the second most popular topic of petitions focused on environmental issues), the e-petition system raised questions about how representative of the electorate the e-petition users were or "the danger of the e-petition system being hijacked by a small group of political activists" (Toland, 2011, 22). The next section will take up this issue of how online petitions may call into question issues of authenticity (of both those initiating and signing the petition) and other ethical issues.

\subsection{Uptake Residues and Online Petition Hoaxes}

Dryer defines "uptake residues" as the intergeneric memories and habitual responses that maintain institutions and interactions $(2016,66)$. These routinized responses that shape our encounters with and uptakes of genre can be both enabling and limiting. Bawarshi (2016) has examined the way that uptakes, informed by rhetorical memory, can pre-condition or over-determine encounters with genres. Drawing on what, by now, is a fairly sedimented understanding of our first amendment right to petition "to seek redress of grievance," these routinized uptakes of the petition genre have been used to perpetuate misinformation about climate change and to appeal to skeptics under the guise of an appeal to authorities by concerned citizens. The petition "30,000 Scientists Reject Anthropogenic Climate Change” has been in circulation since 1998 and was shaped in response to the then Kyoto Protocol. The petition was sponsored by a group calling itself the "Oregon Institute of Science and Medicine," led by a climate change skeptic named Arthur Robinson. Robinson is a biochemist, conservative activist and four-time Republican congressional candidate in Oregon who believes human-driven climate change is a myth. The petition claims that limits 
on greenhouse gases would have harmful effects and that increases in atmospheric carbon dioxide would have beneficial effects (see Figure 2).

\section{Global Warming Petition Project}

\section{1,487 American scientists have signed this petition, including 9,029 with PhDs}

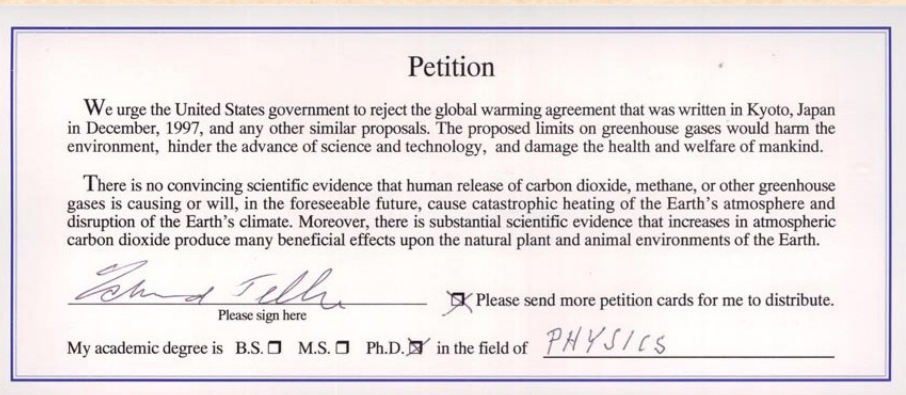

For information about this project, click on the appropriate box below.

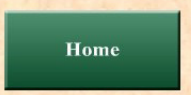

Purpose of Petition

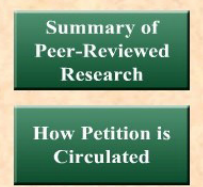

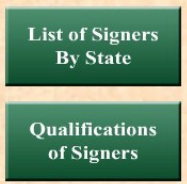

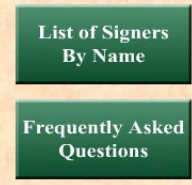

Fig. 2: Hoax Climate Change Petition: http://www.petitionproject.org/index.php.

As of this writing, the sponsoring group claims that the petition has been signed by 31,487 American scientists, although this has never been verified and the veracity of the petition and its signers has been challenged by Politifact.com's "Punditfact," which rated the claim "Pants on Fire" (Greenberg, 2017) and has been debunked by Snopes.com, which rated the petition claims "Mostly False” (Kasprak, 2016), noting that several non-scientists have signed the petition, several names cannot be verified, and several names are of scientists in fields other than climate science. Using accompanying documents, such as a paper printed in the same typeface and format as the official Proceedings of the National Academy of Sciences, the petition was also made to look official, thus further drawing on uptake residues that reminded readers of credible scientific correspondences. The petition was so misleading that the National 
Academy of Science issued the following clarifying statement: “The petition project was a deliberate attempt to mislead scientists and to rally them in an attempt to undermine support for the Kyoto Protocol. The petition was not based on a review of the science of global climate change, nor were its signers experts in the field of climate science" (as cited in Monbiot, 2006). While the petition seems to reflect a normalized uptake and a habitual response by signatories (similar to the rhetorical force of the "World Scientists' Warning to Humanity: A Second Notice," which also includes signatories from the scientific community), the uptake residues of the petition, in this case, are used to undercut and destabilize scientific evidence. As McCright, Dunlap and Xiao (2013) note, "an organized climate change denial movement has mobilized" over the past two decades, and it is able to challenge the scientific consensus and gains its strength, in part, "by amplifying the views of contrarian scientists and generating petitions asserting the lack of consensus" (512; see also Smart \& Falconer, this volume).

While one constraint of petitioning, then, is credibility, especially of online petitions, another constraint is the potential for the petition to reach authorities and to be read and acted upon. boyd notes that "an increase in people's ability to contribute to publics does not necessarily result in the ability to achieve an audience" - or to achieve a response to the petitions. The rhetorical exigency of the petition - of seeking redress from the government regarding grievances - is challenged by what a Northwestern University Law Review article refers to as "downsizing the right to petition," which points out that while we have a constitutional right to petition, there is "not an assurance that communications will receive any particular reception or achieve any particular result” (Lawson \& Seidman, 1999, 2). Richard Hough (2012), in his study of the petition systems of the Australian House of Representatives, the Canadian House of Commons, the German Bundestag, the Scottish Parliament, the UK House of Commons, and the National Assembly for Wales, characterizes the lack of response to petitions as "a parliamentary black hole" (480), although he notes that the ability of petitions to affect policy change varies from legislature to legislature. With the move toward governmental systems of e-petitioning, the challenge in receiving a response is even greater. For example, the UK House of Commons instituted a threshold number of signatures required for a government response to citizen petitions, with a "100,000-signature threshold making an e-petition eligible for a Commons debate" (BBC, 2012). This is the same threshold that was established for the White House petition site "We the People" established by the Obama administration (https://petitions.whitehouse.gov/); however, "the White House has not responded to a petition since Trump took office” (Rosenberg, 2018). Given these affordances and constraints of online petitioning and questions about their efficacy, how can petitions be taken up as tools of mobilization by citizens, and how can they be taken up by authorities who act on and respond to the petition? The uptake enactment of petitions, or response to uptake affordances, will be examined in the next section. We will also examine how, even though petitions might no longer have the rhetorical force 
they once had, they can still be used to direct the climate change debate in ways that might not be in the form of direct action. That is, while we might not see the uptake artifact and enactment of petitions, we can still see affordances and captures and maybe even residues that are actions in the making.

\subsection{Petitions and Uptake Enactments}

This section will focus on uptake enactments of climate change petitions - how they are taken up as tools of mobilization by citizen petitioners and how they are taken up by authorities who act on the petition - and the ways in which public petitions are affected by digital networks that influence the circulation of petitions and their intervention in civic actions. When comparing historical cases of petitioning rooted in the material and physical gathering of petitioners (such as petitions circulated in $19^{\text {th }}$ century women's sewing circles or prerevolutionary petitions hand delivered to the king) to more contemporary online petitions (such as emailed petitions from an online advocacy group like MoveOn.org), there's an obvious shift in the tactical dimensions of the interchange as the sequence of uptakes becomes further removed and increasingly mediated, and there are constraints or limits to political efficacy in digital sites. With online petitions, issues are mobilized across routes of production, circulation, and reception but stop short of execution of action and social change, which is where criticisms of online petitions - as a form of "slactivism" - come in. Howard Rheingold has argued that electronic petitions give people "the illusion that they're participating in some meaningful political action” (cited in Regan, 2002, n.p.) as they quickly sign a petition but then fail to take further action. Just a brief search of online petitions will yield multiple articles with titles such as "Do Online Petitions ever Accomplish Anything?" or "Does Change.org really change anything?” In an ABC Australia article titled “Online Petitions: Do They Have Any Effect?” a university political science lecturer, Dr. Ian Cook, notes, “Just getting a whole bunch of people’s signatures and addresses won't in itself have any effect, you have got to add to it in terms of adding some political pressure” (as cited in Wynne, 2016).

A case in point is a recent Move.on petition to sign onto the Paris climate agreement (see Figure 3), which reached over a half million signatures from across the US (and from Canada). The petition notes that it is "To be delivered to The United States House of Representatives, The United States Senate, and President Donald Trump,” and MoveOn.org notes that they will deliver signatures for approved petitions by email to governors, Congress, and state legislators. "However," they say, "we strongly recommend that you deliver your petition in person to have the maximum impact and ensure that it is seen by your target." Because the online affordances help mobilize knowledge and mobilize support but don't seem to extend to social action, Move.on recommends actions that facilitate uptake enactments, primarily strategies of uptake capture or producing consequences through embodied or affective uptakes. At the end 
of the process of organizing an online petition, Move.on suggests that to deliver the online petition, you should download it and organize a face to face meeting: “There's often no substitute for sitting down and having a conversation with the person you're trying to persuade with your petition. By organizing a meeting, you can present your concerns in greater detail and engage in a back-and-forth discussion about possible solutions. And you'll be $100 \%$ sure that they saw the petition!"

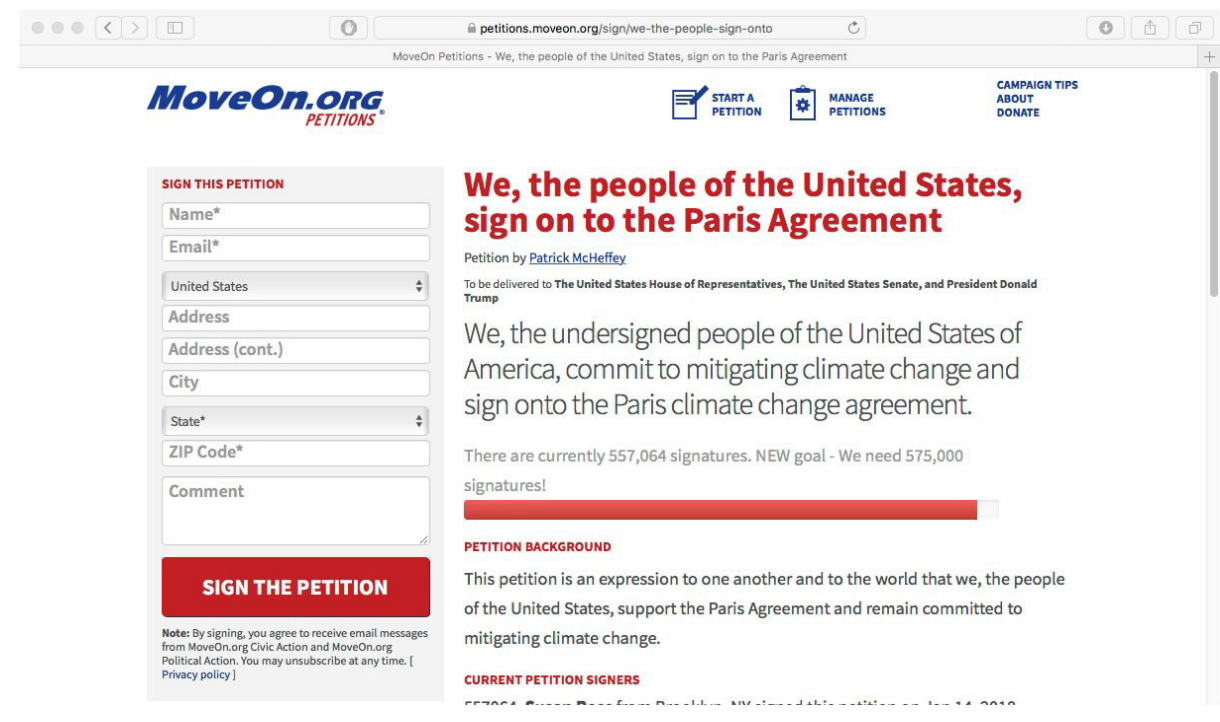

Fig. 3: Moveon.org Petition: https://petitions.moveon.org/sign/we-the-people-signonto.

Actions that further facilitate uptake enactments - and that shape the dispositional, affective and cognitive consequences of uptake capture - consist of "birddogging your target" or approaching your target at a public event or fundraiser (which bears a striking resemblance to the previously described embodied techniques of petitioners in pre-revolutionary England who physically presented their petitions); "simple drop off" of petitions; or "organizing a news conference or rally (which also has historical precedence of organized marches or rallies to present thousands of print petitions). In addition, Moveon.org notes the role of "uptake artifacts" or another genre or text produced in response to other texts. Their site includes "meta-genres" (Giltrow, 2002) or genres that provide guidance in how to produce and negotiate genres and genre uptakes of petitions - that is, tactics for engaging petition signers or for mediating uptakes. These "uptake artifacts" include 1) an email to petition signers to keep them updated on the campaign; 2) a phone call to decision makers; 3) letters to the editor; and 4) flyering events (handing out flyers to invite people to join your petition campaign). The uptake enactment or response to a petition, then, seems to depend on the 
uptakes happening in-between and around the genre. These moments of interaction don't just mobilize petitions but also create affordances for uptake capture, for "lingering effects" that may lead to uptake enactment. Such proto and interstitial actions can play an occluded but powerful role in directing (and redirecting) climate change action.

\subsection{Uptake Enactments: Mobilizing Uptakes, Localizing Uptakes}

How, then, might climate change petitions work to mobilize action on climate change? Political scientist Daniel Carpenter has argued that the rhetorical force of petitions lies not in the response from authorities - the redress of grievances - but in their networking potential, noting that the list of signatories is "a rich political resource" and that in addition to identifying individuals sympathetic to its declaration, the petition and list of signatories "locate individuals in a social structure" (2003, 1). As Carpenter and others have argued, it is worth considering whether the most important readers of a petition are not its recipients but its signatories. The most important function of a petition may not be that it reaches its designated audience but that, in the process, it helps to build discursive networks of affiliation and exchange among political organizers - that it plays a role in coordinating uptakes and coordinating actions that lead to uptake enactments.

The creator of thePetitionsite.com, Randy Paynter, would agree, and in response to charges that online petitions are a form of slactivism, he argues that "Internet petitions are effectively a 'gateway drug' to more civic engagement” (2010, n.p.). Signing a public petition is a public announcement of citizens' support for a cause, "so simple actions that demonstrate that we care about, say the environment, lead to future actions to support the environment (through donations, voting, purchases, discussions with friends, etc.)." Paynter describes the myriad and multi-directional uptakes of petitions: "Sometimes petitions are major factors in a big decision, sometimes they're the triggers that alert international media to hot stories, sometimes they simply raise general awareness of an issue, act as catalysts for fundraising, or compel other power brokers to get involved" (2010, n.p.). Climate change petitions, then, might act as the "gateway drug" to more transformative action on climate change. As part of this mobilization process, participants in local publics, such as academics, might also play a role in mobilizing action on issues like climate change that affect a larger public. While academics might not consider themselves "power brokers" by any means, Audrey Williams June (2017), in an article in The Chronicle of Higher Education, weighs in on the political efficacy (or uptake enactment) of petitions, noting that while petition use has become more prevalent among faculty who "have sounded off on issues like climate change, academic freedom, and the rights of transgender people.... It's not clear whether petitions signed by academics have more heft than others or if they have much of an effect at all. Recent efforts suggest that those that 
apply directly to academe seem to be more successful than those that opine on things far from campus" (n.p.). The article goes on to examine petitions that received a sizable number of signatures and their outcomes (or uptake enactments), and it's clear that more localized efforts - for example, to change the name of Yale University's Calhoun College (named after an advocate of slavery) or to reinstate two faculty members who had been fired from Mount St. Mary's University - were more successful in producing a response than more dispersed, national efforts (for example, a petition to intervene and stop Jeff Sessions from being confirmed as Attorney General).

The importance of localized efforts also seems to be driving recent climate change activism and petition drives, with a series of petitions by Moveon.org to "Urge your Governor to Support the Paris Climate Agreement" (See Figure 4). The main petition site notes that, in response to Trump pulling out of the Paris Climate Agreement, "governors from California, New York, and Washington launched the US Climate Alliance, a coalition committed to the carbon reduction efforts called for under the Paris Agreement. So far, 14 states and Puerto Rico have joined the US Climate Alliance. Now, MoveOn members across the country are petitioning their states to join them." Individuals are asked to click on the map to join a petition drive in their state, with the petition gathering signatures of residents of the state and sending the petition to the state governor, thus making the uptake less dispersed and less distant and perhaps strengthening the possibility of uptake enactment and mobilizing a response to climate change.

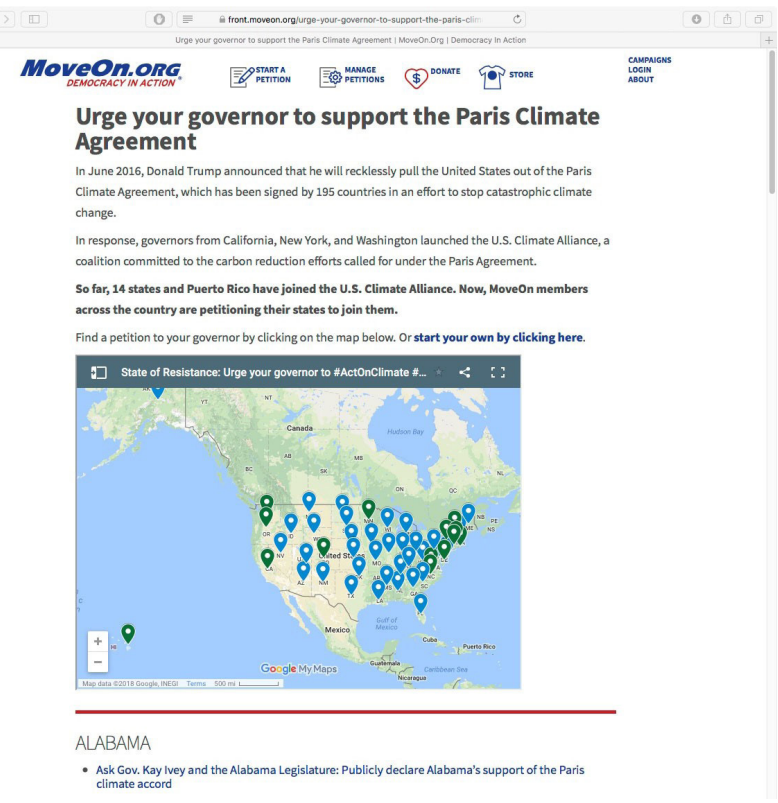

Fig. 4: Moveon.org: https://front.moveon.org/urge-your-governor-to-support-theparis-climate-agreement/\#.WlvssktG1E5. 


\subsection{Conclusion}

Recognizing the urgency to act - and noting that "humanity is not taking the urgent steps needed to safeguard our imperiled biosphere" (Ripple et al., 2017, 1026) - the authors and signatories of the Second Notice warning to humanity indicate how this urgency might translate to action:

As most political leaders respond to pressure, scientists, media influencers, and lay citizens must insist that their governments take immediate action as a moral imperative to current and future generations of human and other life. With a groundswell of organized grassroots efforts, dogged opposition can be overcome and political leaders compelled to do the right thing. (Ripple et al., 2017, 1026)

The authors describe the role citizens must play in motivating their governments to take action through grassroots efforts, efforts that petitions and other genres can help to mobilize. But as our chapter's analysis has hopefully illustrated, the mobilization of scientific knowledge into action requires not just genre work but uptake work. It requires paying attention to the pathways drawn and relations held between genres that make movements and translations of knowledge across genres possible. By focusing on the seams that hold between genres, we can both better understand what makes certain uptake selections (and not others) possible and more effectively intervene in, broker, and sponsor these uptake selections.

Historically, petitions have been uniquely positioned to generate and mobilize a groundswell of grassroots efforts, yet our examination of petitions (and their uptakes) as complex sites of transaction also draws attention to the mobilizations and actions that may happen along the pathway to uptake and social action - what we described as mobilizations in process. That is, petitions can help us trace what Deleuze and Guattari (1987) call "directions in motion" (21) as the act of petitioning, signing petitions, and distributing them can intervene in, direct, and re-direct uptakes. As we hope our chapter has demonstrated, recognizing the complex uptakes surrounding petitioning reveals how genres can be used to intervene in and redirect climate change action.

As Devitt (this volume) argues, "genres work for social action rather than only as social actions when people act through them deliberately, consciously, and toward desired ends. Genres always already are social actions ... But critical awareness of those social actions can transform everyday social actions that get things done in the world into powerful actions with social and political purpose, actions meant to alter the world in meaningful and even structural ways" (add page \#). As we seek to understand how public genres, like petitions, act in the world - and to understand how public petitions might lead to greater awareness and action on climate change it is helpful then to examine not only uptake enactment (the result of genre action) but also the social, affective, and material interactions that happen around and in between genres and that limit or enable genre action. A better understanding of the 
complexity of uptakes - and their complex scene of agency - can help us understand that taking up the affordances of a petition by circulating or signing a petition on climate change is not enough and is just a step - or one uptake pathway - in facilitating action through uptake artifacts (follow-up emails, phone calls to leaders, letters to the editor, flyering events) or uptake capture (organizing face to face delivery, birddogging the target of the petition, organizing a rally or march to present a petition). We might also consider how localized or place-based uptakes might be more effective in bringing about change in climate debates and action, as we consider a vision of genre as [social] movement - "interrelationships drawing together configurations of conventions into (perceived) recurrence in particular places and times" (Dryer, 2016, 61). If a petition is a tool of mobilization, then it can mobilize climate change action in multiple and different directions, from raising awareness of issues, to helping organizations fundraise, to drawing media attention, to drawing the attention of the authorities it seeks to persuade. Understanding these multiple uptake pathways and uptake enactments can help us construct uptake-enactment strategies that can "turn accumulated knowledge into action” and can lead to genres for social action and change.

\section{References}

Alliance of World Scientists (2017). Retrieved from http://scientistswarning.forestry.oregonstate.edu Auken, S. (2015a). Genre and interpretation. In S. Auken, P.S. Lauridsen, \& A.J. Rasmussen (Eds.), Genre and ... (154-183). Copenhagen: Ekbátana (Copenhagen Studies in Genre; vol. 2).

Auken, S. (2015b). Utterance and function in genre studies: A literary perspective. In J. Andersen (Ed.), Genre theory in information studies (155-78). Bingley: Emerald Group Publishing Limited. doi:10.1108/S2055-537720140000011009.

Auken, S. (2018). Understanding genre. Journal of Zhejiang International Studies University, 2, $14-27$.

Austin, J.L. (1962). How to do things with words. Oxford: Oxford University Press.

Bailey, R.C. (1979). Popular influence upon public policy: Petitioning in eighteenth-century Virginia. Westport, CT: Greenwood.

Barad, K. (2007). Meeting the universe halfway: Quantum physics and the entanglement of matter and meaning. Durham: Duke University Press.

Bawarshi, A. (2016). Between genres: Uptake, memory, and US public discourse on Israel-Palestine. In M.J. Reiff \& A. Bawarshi (Eds.), Genre and the performance of publics (43-59). Logan: Utah State University Press. doi:10.7330/9781607324430.c002.

Bawarshi, A., \& Reiff, M.J. (Eds.) (2010). Genre: An introduction to history, theory, research, and pedagogy. West Lafayette, IN: Parlor Press.

BBC (2012, September 13). More e-petitions to receive government responses. Retrieved from https://www.bbc.com/news/uk-politics-19583777.

boyd, d. (2010). Social network sites as networked publics: Affordances, dynamics, and implications. In Z. Papacharissi (Ed.), A networked self: identity, community, and culture on social network sites (39-58). New York: Routledge.

Carpenter, D. (2003). The petition as a tool of recruitment: Evidence from the Abolitionist Congressional Campaign. Prepared for presentation at the Crafting and Operating Institutions 
Conference at Yale University, 1-36. Retrieved from https://petitions.radcliffe.harvard.edu/ files/petitions/files/petition-recruit-20040112.pdf.

Chen, J. (2016). Useful complaints: How petitions assist decentralized authoritarianism in China. London: Lexington Books.

Deleuze, G., \& Guattari, F. (1987). A thousand plateaus: Capitalism and schizophrenia (Brian Massumi, Trans.). Minneapolis, MN: University of Minnesota Press.

Devitt, A.J. (2018). Genre for social action: Transforming worlds through genre awareness and action. This publication.

Dryer, D. (2016). Disambiguating uptake: Toward a tactical research agenda on citizens' writing. In M.J. Reiff \& A. Bawarshi (Eds.), Genre and the performance of publics (60-79). Logan: Utah State University Press. doi:10.7330/9781607324430.c003.

Dryer, D. (2008). Taking up space: Genre systems as geographies of the possible. JAC: Rhetoric, Writing, Culture, Politics, 28(3/4), 505-34.

Dunlap, R.E. (2013). Climate change skepticism and denial: An introduction. American Behavioral Scientist, 57, 691-698. doi:10.1177/0002764213477097.

Freadman, A. (1994). Anyone for tennis? In A. Freedman \& P. Medway (Eds.), Genre and the new rhetoric (43-66). London: Taylor \& Francis.

Freadman, A. (2002). Uptake. In R. Coe, L. Lingard, \& T. Teslenko (Eds.), The rhetoric and ideology of genre (39-53). Cresskill: Hampton Press.

Freadman, A. (2004). The machinery of talk: Charles Peirce and the sign hypothesis. Stanford: Stanford University Press.

Freadman, A. (2012). The trap and trappings of genre theory. Applied Linguistics, 33(5), 544-63. doi:10.1093/applin/ams050.

Freadman, A. (2014). Where is the subject? Rhetorical genre theory and the question of the writer. Journal of Academic Language and Learning, 8(3), A1-11.

Freedman, A., \& Medway, P. (Eds.) (1994). Genre and the new rhetoric. London: Taylor \& Francis.

Giltrow, J. (2002). Meta-genre. In R. Coe, L. Lingard, \& T. Teslenko (Eds.), The rhetoric and ideology of genre (187-205). Cresskill: Hampton Press.

Gramsci, A. (1971). Selections from the prison notebooks. (Q. Hoare \& G. Nowell Smith, Trans). London: Lawrence and Wishart.

Graubart, J. (2008). Legalizing transnational activism: The struggle to gain social change from NAFTA's citizen petitions. University Park, PA: The Pennsylvania State University Press.

Greenberg, J. (2017, September 8). No, 30,000 scientists have not said climate change is a hoax. Politifact. Retrieved from http://www.politifact.com/punditfact/statements/2017/sep/08/ blog-posting/no-30000-scientists-have-not-said-climate-change-h/.

Gregory, J. (2015, June 23). Authenticating electronic petitions. Slaw: Canada's Online Legal Magazine. Retrieved from http://www.slaw.ca/2015/06/23/authenticating-electronicpetitions/

Hale, S. (2010). The new politics of climate change: Why we are failing and how we will succeed. Environmental Politics, 19(2), 255-275. doi:10.1080/09644010903576900.

Hamilton, C. (2010). Requiem for a species: Why we resist the truth about climate change. Crows Nest, New South Wales, Australia: Allen \& Unwin.

Hough, R. (2012). Do legislative petition systems enhance the relationship between parliament and citizen? The Journal of Legislative Studies, 18(3-4), 479-495. doi:10.1080/13572334.2012.7 06057.

Jacques, P.J. (2006). The rearguard of modernity: Environmental skepticism as a struggle of citizenship. Global Environmental Politics, 6, 76-101. doi:10.1162/glep.2006.6.1.76.

June, A.W. (2017). Through petitions, professors exercise a special duty to speak out. The Chronicle of Higher Education, 63(27). Retrieved from https://www.chronicle.com/article/ThroughPetitions-Professors/239334. 
Kasprak, A. (2016). Not all climatologists. Snopes. Retrieved from https://www.snopes.com/ fact-check/30000-scientists-reject-climate-change/.

Kelly, B. (2011). Petitions, litigation, and social control in Roman Egypt. Oxford: Oxford University Press.

Lawson, G., \& Seidman, G. (1999). Downsizing the right to petition. Northwestern University Law Review, 93(3), 1-27.

Maier, P. (1991). From resistance to revolution: Colonial radicals and the development of American opposition to Britain, 1765-1776. New York, NY: Norton.

McCright, A.M., Dunlap, R.E, \& Xiao, C. (2013). Perceived scientific agreement and support for government action on climate change in the USA. Climatic Change, 119, 511-518.

Miller, W.L. (1995). Arguing about slavery: John Quincy Adams and the Great Battle in the United States Congress. New York, NY: Vintage.

Monbiot, G. (2006, September 19). The denial industry. The Guardian. Retrieved from https://www. theguardian.com/environment/2006/sep/19/ethicalliving.g2.

Osofsky, H.M. (2007). The Inuit petition as a bridge? Beyond dialectics of climate change and Indigenous peoples' rights. American Indian Law Review, 31(2), 675-697. doi:10.2307/20070803.

Paynter, R. (2010, April 28). Slacktivism: Why snopes got it wrong about internet petitions. Care2. com. Retrieved from http://www.care2services.com/care2blog/slacktivism-why-snopes-got-itwrong-about-internet-petitions.

Portnoy, A. (2005). Their right to speak: Women's activism in the Indian and slave debates. Cambridge, MA: Harvard University Press.

Regan, M.P. (2002). Online activism _ a lot more than just petitions. Retrieved from http://www. greenday.net/activism.html.

Reiff, M.J. (2016). Geographies of public genres: Navigating rhetorical and material relations of the public petition. In M.J. Reiff \& A. Bawarshi (Eds.), Genre and the performance of publics (100-116). Logan: Utah State University Press. doi:10.7330/9781607324430.c005.

Ripple, W.J., Wolf, C., Newsome, T.M., Galetti, M., Alamgir, M., Crist, E., Mahmoud, M.I., \& Laurance, W.F. (2017). World scientists' warning to humanity: A second notice. BioScience, 67(12), 1026-1028. doi:10.1093/biosci/bix125.

Rosenberg, E. (2018, February 1). The White House has finally restored a petitions site that is critical of President Trump. The Washington Post. Retrieved from https://www.washingtonpost.com/ news/the-fix/wp/2018/01/31/the-white-house-promised-to-restore-a-petitions-site-that-wascritical-of-trump-it-hasnt/?utm_term $=.8927100 \mathrm{fbb} 46$.

ScienceDaily (2017, August 15). Understanding alternative reasons for denying climate change could help bridge divide. ScienceDaily. Retrieved from https://www.sciencedaily.com/ releases/2017/08/170815095049.htm.

Swales, J.M. (1990). Genre analysis: English in academic and research settings. Cambridge: Cambridge University Press.

Swales, J.M. (2004). Research genres: Explorations and applications. Cambridge: Cambridge University Press.

Tachino, T. (2012). Theorizing uptake and knowledge mobilization: A case for intermediary genre. Written Communication, 29, 455-476. doi:10.1177/0741088312457908.

Tachino, T. (2016). Multiple intertextual threads and (un)likely uptakes: An analysis of a Canadian public inquiry. In M.J. Reiff \& A. Bawarshi (Eds.), Genre and the performance of publics (178-198). Logan: Utah State University Press. doi:10.7330/9781607324430.c009.

Thieme, K. (2006). Uptake and genre: The Canadian reception of suffrage militancy. Women's Studies International Forum, 29, 279-288. doi:10.1016/j.wsif.2006.04.007.

Thompson, M. (2003). Cultural theory, climate change and clumsiness. Economic and Political Weekly, 38, 5107-5112. 
Toland, J. (2011). E-petitions in local government: the case of Wellington city council. International Reports on Socio-Informatics, 8(2), 15-22.

Van Rensburg, W., \& Head, B.W. (2017). Climate change scepticism: Reconsidering how to respond to core criticisms of climate science and policy. Sage Open, 7(4), 1-11. doi: $10.1177 / 2158244017748983$.

Van Voss, L.H. (2001). Petitions in social history. Cambridge: University of Cambridge Press.

Whitmarsh, L. (2011). Scepticism and uncertainty about climate change: Dimensions, determinants and change over time. Global Environmental Change, 21, 690-700. doi:10.1016/j. gloenvcha.2011.01.016.

Wynne, E. (2016, December 15). Online petitions: Do they have any effect? ABC Radio Perth. Retrieved from http://www.abc.net.au/news/2016-12-15/are-online-petitions-evereffective/8124388.

Zaeske, S. (2003). Signatures of citizenship: Petitioning, antislavery, and women's political identity. Chapel Hill: University of North Carolina Press.

Zaret, D. (2000). Origins of democratic culture: Printing, petitions, and the public sphere in early-modern England. Princeton, NJ: Princeton University Press. 